\title{
ІНВАЗИВНИЙ РАК НЕСПЕЦИФІЧНОГО ТИПУ МОЛОЧНОЇ ЗАЛОЗИ: ГІСТОЛОГІЧНІ ТА ІМУНОГІСТОХІМІЧНІ ОСОБЛИВОСТІ
}

\author{
Линдін М. С., Романюк А. М.
}

\section{ВСТУП}

Рак молочної залози (РМЗ) є найбільш частою злоякісною пухлиною у жінок та другою за частотою, після раку легень, онкологічною патологією в популяції взагалі. Причинами виникнення РМЗ $\epsilon$ дисгормональні розлади, спадкова схильність, фактори зовнішнього середовища та інші ${ }^{1,2,3}$. На сьогодні описано 26 типів інвазивних форм РМЗ, серед яких у 50-80\% випадках у біопсійному та післяопераційному матеріалі виявляється інвазивний рак неспецифічного типу $\left(\right.$ IPHT) ${ }^{4,5}$. Цей тип карцином молочної залози позбавлений достатньої кількості специфічних ознак для однозначного встановлення діагнозу IPHТ, іноді потребуючи додаткових імуногістохімічних досліджень для встановлення остаточного діагнозу. Діагноз IPHT молочної залози потребує обов'язкового встановлення ступеню диференціювання новоутворення та його імуногістохімічного профілю. Саме ці критерії морфологічного дослідження $\epsilon$ передумовою призначення протипухлинної терапії та прогнозування перебігу захворювання ${ }^{6}$.

Перебіг РМЗ залежить не тільки від особливостей паренхіматозного компоненту пухлин, а також від якісних характеристик строми.

${ }^{1}$ Wu Y., Zhang D., Kang S. Physical activity and risk of breast cancer: a metaanalysis of prospective studies. Breast Cancer Res Treat. 2013. Vol. 137, № 3. P. 869882. doi:10.1007/s10549-012-2396-7.

${ }^{2}$ Suba Z. Triple-negative breast cancer risk in women is defined by the defect of estrogen signaling: preventive and therapeutic implications. Onco Targets Ther. 2014. Vol. 7. P. 147-164. doi:10.2147/OTT.S52600.

${ }^{3}$ Apostolou P., Fostira F. Hereditary breast cancer: the era of new susceptibility genes. Biomed Res Int. 2013. 2013:747318. doi:10.1155/2013/747318.

${ }^{4}$ Tavassoli F.A., Devilee P. Tumor of the Breast and female genital organs. World Health Organization Classification of Tumours : Lyon: IARC Press, 2003. 432 p.

${ }^{5}$ Lakhani S.R., Ellis I.O., Schnitt S.J., Tan P.H. Invasive carcinoma of no special type. WHO Classification of Tumours of the Breast : Lyon, 2012. 34-38 p.

${ }^{6}$ Sørlie T., Perou C.M., Tibshirani R., et al. Gene expression patterns of breast carcinomas distinguish tumor subclasses with clinical implications. Proc Natl Acad Sci USA. 2001. Vol. 98, № 19. P. 10869-10874. doi:10.1073/pnas.191367098. 
Встановлено, що патологічна біомінералізація та рівень імунної реакції вливають на морфогенез новоутворень ${ }^{7,8}$. Відкладання солей кальцію у вигляді гідроксиапатиту корелює 3 наявністю інвазивних форм РМЗ. 3 іншого боку, перебіг захворювання погіршується за присутності в пухлинному мікрооточенні $\mathrm{CD}^{+}$T-лімфоцитів 2-го типу і В-лімфоцитів ${ }^{9}$.

Рецепторний профіль неопластичних клітин РМ3 має один із найпотужніших прогностичних i терапевтичних впливів. Пухлинна трансформація у молочній залозі супроводжується ескалацією експресії рецепторів до естрогену (ЕР) та прогестерону (ПР), оберненопропорційно корелюючи зі ступенем диференціювання карцином та впливаючи на чутливість до антигормональних препаратів ${ }^{10}$. При рецептор-позитивного статусі РМЗ пухлина є відносно керованою та контрольованою антиестрогенною терапією. Слід зазначити, що якість терапевтичного ефекту залежить як від наявності ЕР та ПР, так і від їх кількості ${ }^{11}$. Підступність рецепторів 2-го типу людського епідермального фактору росту (HER2/neu) стимулює пухлину до самозростання, знижуючи виживаність пацієнтів та індукуючи резистентність неопластичних клітин до хіміотерапії ${ }^{12}$.

Перебіг РМЗ залежить від проліферативної активності пухлинних клітин та їх здатності до апоптозу. Вивчення експресії білків Кі-67, які наявні у клітинах у стані поділу, дозволяе визначити ступінь злоякісності карцином та визначити ефективність протипухлинної

${ }^{7}$ Cox R.F., Hernandez-Santana A., Ramdass S., McMahon G., Harmey J.H., Morgan M.P. Microcalcifications in breast cancer: novel insights into the molecular mechanism and functional consequence of mammary mineralisation. Br J Cancer. 2012. Vol. 106, № 3. P.525-537. doi:10.1038/bjc.2011.583.

${ }^{8}$ Keibel A., Singh V., Sharma M. C. Inflammation, microenvironment, and the immune system in cancer progression. Curr Pharm Des. 2009. Vol. 15, № 17. P. 19491955. doi:10.2174/138161209788453167.

${ }^{9}$ Ruffell B., Au A., Rugo H.S., Esserman L.J., Hwang E.S., Coussens L.M. Leukocyte composition of human breast cancer. Proc Natl Acad Sci U S A. 2012. Vol. 109, №8. P. 2796-2801. doi:10.1073/pnas.1104303108.

${ }^{10}$ Lindström L.S., Karlsson E., Wilking U.M., et al. Clinically used breast cancer markers such as estrogen receptor, progesterone receptor, and human epidermal growth factor receptor 2 are unstable throughout tumor progression. J Clin Oncol. 2012. Vol. 30, № 21. P. 2601-2608. doi:10.1200/JCO.2011.37.2482.

${ }^{11}$ Esslimani-Sahla M., Kramar A., Simony-Lafontaine J., Warner M., Gustafsson J.A., Rochefort $H$. Increased estrogen receptor betacx expression during mammary carcinogenesis. Clin Cancer Res. 2005. Vol. 11, № 9. P. 3170-3174. doi:10.1158/10780432.CCR-04-2298.

${ }^{12}$ Glück S., Arteaga C.L., Osborne C.K. Optimizing chemotherapy-free survival for the ER/HER2-positive metastatic breast cancer patient. Clin Cancer Res. 2011. Vol. 17, № 17. P. 5559-5561. doi:10.1158/1078-0432.CCR-10-2051. 
терапії ${ }^{13}$. 3 іншого боку, встановлення про- або антиапоптозного потенціалу пухлинних клітин у тканині РМЗ за рахунок визначення експресії білків p53 та bcl-2 є підгрунтям для дослідження готовності ракових клітин до індукованої загибелі ${ }^{14,15}$. Слід зазначити, що визначені маркери $\epsilon$ найбільш вивченими в пухлинах людського організму та мають велику кількість спільних механізмів впливу як на неопластичні клітини, так і один на одного.

Серед інших прогностичних маркерів велика увага приділяється визначенню експресії остеопонтину, шаперонів, матриксних металопротеїназ (ММП), кадгеринів та ендотеліального судинного фактору росту (ЕСФР) у непластичних тканинах ${ }^{16,17,18,19,20}$. Ці білки впливають на перебіг злоякісного процесу, беручи участь у регуляції клітинної міграції, здатності до апоптозу, ступены неоваскуляризації пухлинної тканини, рівня імунної відповіді на наявність чужорідних клітин, поширення їх у навколишні тканини та якісний склад мікрооточення.

Варто зазначити, що прогресування РМЗ супроводжується варіабельністю морфологічних та імуногістохімічних особливостей новоутворень, що, без сумніву, відображається на поведінці пухлин та їх терапевтично-прогностичних особливостях. Тому комплексне обстеження тканини РМЗ $є$ ключовим етапом у персоналізації лікування хворих.

${ }^{13}$ Weigel M.T., Dowsett M. Current and emerging biomarkers in breast cancer: prognosis and prediction. Endocr Relat Cancer. 2010. Vol. 17, № 4. P. R245-R262. doi:10.1677/ERC-10-0136.

${ }^{14}$ Al-azawi D., Leong S., Wong L., Kay E., Hill A. D., Young L. HER-2 positive and p53 negative breast cancers are associated with poor prognosis. Cancer Invest. 2011. Vol. 29, № 5. P. 365-369. doi:10.3109/07357907.2011.584586.

${ }^{15}$ Martin L.A., Dowsett M. BCL-2: a new therapeutic target in estrogen receptor-positive breast cancer?. Cancer Cell. 2013. Vol. 24, №1. P. 7-9. doi:10.1016/j.ccr.2013.06.006.

16 Wang X., Chao L., Ma G., et al. Primary breast carcinoma: association of mammographic calcifications with osteopontin expression. Radiology. 2010. Vol. 254, № 1. P. 69-78. doi:10.1148/radiol.2541090675.

${ }^{17}$ Grbovic O.M., Basso A.D., Sawai A., et al. V600E B-Raf requires the Hsp90 chaperone for stability and is degraded in response to Hsp90 inhibitors. Proc Natl Acad Sci USA. 2006. Vol. 103, № 1. P. 57-62. doi:10.1073/pnas.0609973103.

18 Kaimal R., Aljumaily R., Tressel S.L., et al. Selective blockade of matrix metalloprotease-14 with a monoclonal antibody abrogates invasion, angiogenesis, and tumor growth in ovarian cancer. Cancer Res. 2013. Vol. 73, № 8. P. 2457-2467. doi:10.1158/0008-5472.CAN-12-1426.

19 Brzozowska A., Sodolski T., Duma D., Mazurkiewicz T., Mazurkiewicz M. Evaluation of prognostic parameters of E-cadherin status in breast cancer treatment. Ann Agric Environ Med. 2012. Vol. 19, № 3. P. 541-546.

${ }^{20}$ Li X., Lee C., Tang Z., et al. VEGF-B: a survival, or an angiogenic factor? Cell Adh Migr. 2009. Vol. 3, № 4. P. 322-327. doi: 10.4161/cam.3.4.9459. 


\section{1. Епідеміологічні, макро- та мікроскопічні особливості РМЗ}

Захворюваність на злоякісні пухлини в Україні знаходиться на високому рівні (рис. 1), у середньому складаючи $332,52 \pm 19,46$ на 100 тис. населення. Серед них 71,5\% припадає на міське населення, $28,5 \%$ випадків виявлено у жителів сільської місцевості. РМЗ займає одну 3 лідируючих позицій у структурі онкологічної патології - за останні 10 років цей показник у середньому дорівнює $64,51 \pm 2,85$ на 100 тис. населення. Більшість випадків $(99,2 \%)$ виявлено в пацієнтів жіночої статі, і лише $0,8 \%$ випадків спостерігалося у чоловіків.
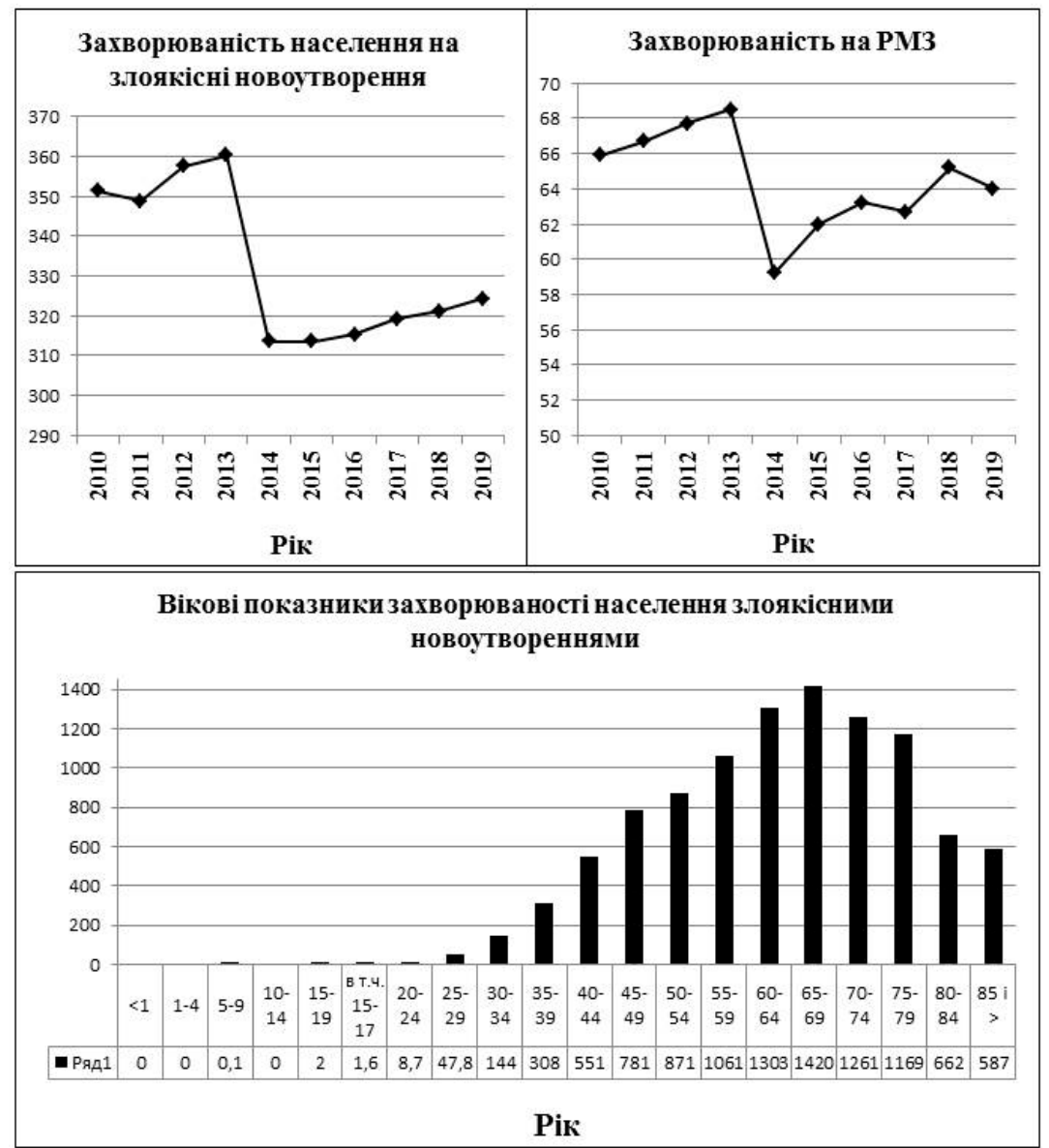

Рис. 1. Показники захворюваності на злоякісні пухлини (в тому числі РМЗ) в Україні у період з 2010 по 2019 рр на 100 тис. населення 
Незважаючи на незначне покращення показників, починаючи 3 2014 року спостерігається тенденція до наближення показників захворюваності на злоякісні пухлини, у тому числі і РМЗ, до рівня попередніх років. Основний пік ураження молочних залоз злоякісними пухлинами виявлено в жінок у постменопаузному періоді з поступовим зниженням цього показника в людей літнього віку (рис. 1). 3 одного боку, це пов'язано з віковою та дисгормональною залежністю розвитку РМЗ. 3 іншого боку, регрес у захворюваності після 70 років є прямо пропорційним відображенням загальної виживаності людей у цьому віці. Серед усіх морфологічних форм РМЗ більша половина випадків має гістологічний діагноз «Інвазивний рак неспецифічного типу» різного ступеню диференціювання 3 та без метастатичного ураження лімфатичних вузлів та інших органів.

Під час морфологічного дослідження матеріалу при IPHT молочної залози сапостерігається вузлове ураження МЗ. У більшості випадків відсутні чіткі контури пухлини. Вони мають в основному щільну консистенцію, різко відрізняючись від навколишньої тканини, з якою новоутворення міцно пов'язані. Поверхня зрізу має сірий колір, іноді наявні крововиливи, кальцифікати, які визначалися візуально або за характерним звуком під час проведення розрізу, та вогнища некрозу жовтого кольору. Розміри зони ураження коливаються від 1,3 см до 12,0 см у діаметрі. Контури ракового вузла в більшості випадків нерівні та у вигляді тяжів, які проникають у тканину МЗ 3 формуванням зірчастої конфігурації. Статистичнодостовірної різниці у локалізації цього виду пухлини, порівнюючи 3 іншими гістологічними варіантами, не виявлено - майже однакова їх кількість виявлена лівій та правій МЗ. Інколи спостерігається двобічне ураження залоз. Більша кількість випадків виявляється на I-II стадіях захворювання зі зростанням цього показника упродовж останніх років. Досить часто метастатичне ураження лімфатичних вузлів не залежить від розміру первинного вогнища, що вказує на незалежність віддаленого поширення пухлини від місцевого розростання новоутворення у МЗ.

При гістологічному дослідженні у тканині ІРНТ виявлено наявність гнізд, трабекул та кластерів, які представлені пухлинними клітинами. Частина випадків характеризується солідним ростом із різним ступенем розвитку строми. Неопластичні клітини мають різний ступінь прояву атипізму. Цитоплазма частіше добре виражена та еозинофільна. Ядра округлі, мономорфні або з вираженим поліморфізмом, добре помітні ядерця. Мітотична активність клітин виражена по-різному - від повної відсутності до більш ніж 20 мітозів в одному полі зору. В оточуючих ділянках іноді наявні вогнища протокової карциноми in situ. У неопластичній тканині виявляються ділянки крововиливів, некрозів, петрифікації та гіалінозу. При дедиференціюванні пухлин зростає частка 
пухлинної тканини із солідним або трабекулярним характером росту клітин, які іноді розташовуються відокремлено та у вигляді ланцюжків.

Морфологічні особливості будови пухлинної тканини та рівень проліферативної активності та атипізму клітин дозволяє розділити всі випадки IPHТ за ступенем диференціювання. Для пухлин низького ступеню злоякісності (low-grade) притаманним є наявність тубулозалосистих структурна більше ніж 75\% площі препарату (рис. 2 - А). Переважна кількість клітин має правильну (циліндричну або кубічну) форму, дрібні мономорфні ядра. Клітини вистилають пухлинні утворення в один ряд - відсутній базальний шар клітин. Інколи виявляється різний ступінь прояву ядерного і клітинного поліморфізму. Мітотична активність знаходиться на доволі низькому рівні та не перевищує 15 мітозів у 10 полях зору при збільшенні мікроскопу $\times 400$. Ключовим моментом $\epsilon$ наявність у стромі окремих пухлинних комплексів, що $є$ індикатором інвазивного характеру росту неоплазії. Вторинні зміни є нехарактерними для low-grade IPHT.

Пухлини 3 високим злоякісним потенціалом (high-grade) характеризуються зменшенням площі, представленої тубулярними структурами, до повного іiї зникнення (рис. 2 - Б). Неопластичні клітини проявляють різний ступінь клітинного та ядерного атипізму зі зростанням їх проліферативного потенціалу, який перевищує 15 мітозів у 10 полях зору. Для цього ступеню диференціювання пухлин притаманним $є$ як скірозний варіант тип росту за умови переважання та гіалінозу строми та окремо розсіяними або у вигляді ланцюжків неопластичними клітинами, так і майже тотального розростання ракових клітин при незначному стромальному компоненті. У препаратах іноді наявні виродливі та багатоядерні клітини з вираженим гіперхроматозом ядер. Ракові клітини іноді мають лімфоцитоподібні форму та розміри 3 майже непомітною цитоплазмою. В основному неопластична тканина складається з досить великих клітин із доволі вираженою еозинофільною цитоплазмою та гіперхромними ядрама і одним або кількома ядерцями. Клітини майже завжди зберігають здатність до адгезії між собою. У неопластичній тканині часто візуалізуються петрифікати, некрози, крововиливи та запальна інфільтрація.

Слід зазначити, що low-grade IPHT молочної залози зустрічаються значно рідше (близько 20\%), ніж high-grade карциноми. При дедиференціюванні новоутворень відбувається зростання метастатичного потенціалу новоутвореної тканини та підвищення іï проліферативна активність. Останні більш яскраво виражена в периферичних ділянках пухлини порівняно 3 прицентральними зонами. Залучення до непластичного процесу шкіри та віддалене поширення пухлини в інші органи спостерігається виключно в низькодиференційованих пухлинах. 


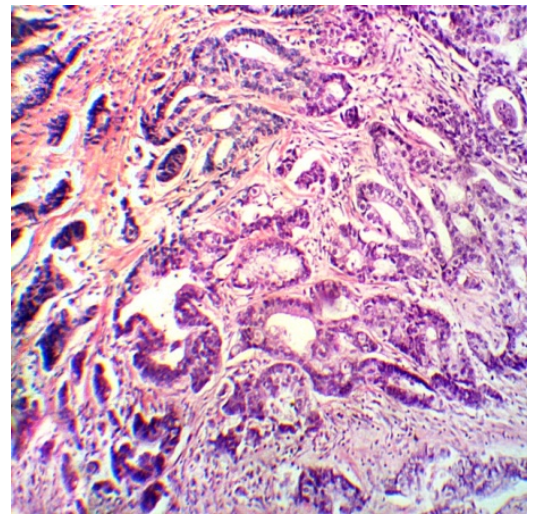

A

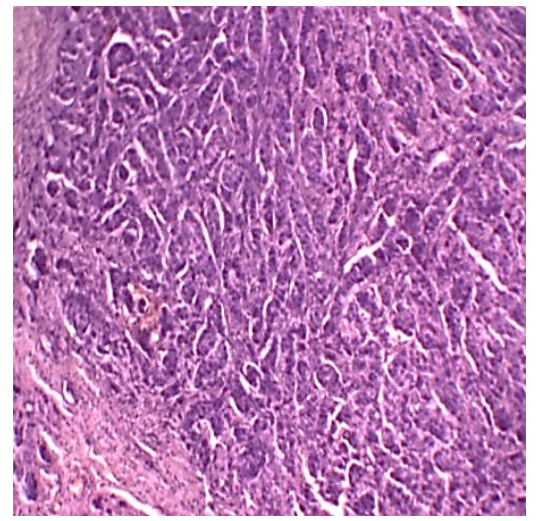

Б

Рис. 2. IPHT різного ступеню диференціювання: A - low-grade, Б - high-grade. Забарвлення гематоксиліном та еозином. Збільшення $\times 100$

Явища патологічної кальцифікації (петрифікації), яка спостерігається у близько $35 \%$ випадків, виявлено в усіх складових компонентах неопластичної тканини IРНT (паренхімі та стромі). Вони представлені вогнищевим згрупованим відкладанням солей кальцію та дифузнорозташованими розрізненими петрифікатами різної форми та розмірів (рис. 3). Додаткове дослідження препаратів при їх забарвленні алізариновим червоним $\mathrm{S}$ дозволило візуалізувати не тільки кальцій-позитивний сигнал у складі петрифікатів, але і в їх навколишніх ділянках та в цитоплазмі неопластичних клітин. Щодо перифокальної реакції навколо кальцифікатів, то вона має різний ступінь прояву зі зменшенням інтенсивності сигналу в більш віддалених ділянках. Це слугує індикатором прогресуючого характеру відкладання кальцій-вмісних солей у неопластичній тканині та послідуючим ущільненням структури петрифікатів.

Наявність імунної реакції у тканині ІРНТ спостерігається приблизно у 45\% випадків. Вона представлена лімфоцитами, гістіоцитами (макрофагами), сегментоядерними лейкоцитами та поодинокими плазмацитами. Вони можуть розташовуватись як розрізнено, так i утворюючи трабекуло- та нодулоподібні скупчення. Іноді рівень цієї реакції настільки виражений, що в неопластичній тканині виявляються фолікулоподібні утворення із центрами розмноження або відмічається майже повне заміщення стромального компоненту імуноцитами. Довготривалість процесу інколи супроводжується гранулематозною реакцією, у складі якої виявляються багатоядерні клітини за типом клітин «сторонніх тіл». Це $\epsilon$ індикатором толерантності імунної відповіді на персистуючий провокуючий фактор (пухлину). 


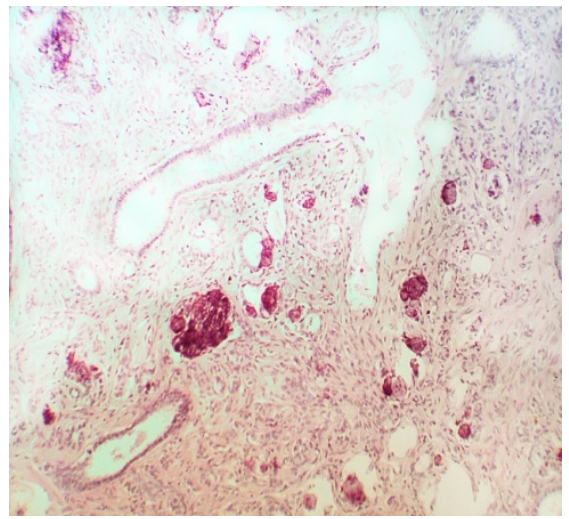

A

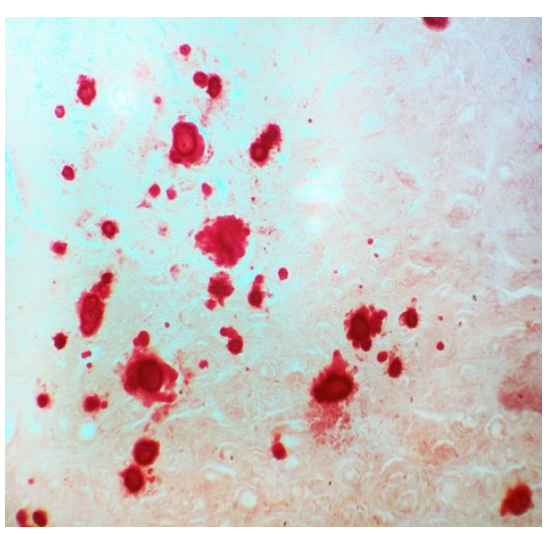

Б

Рис. 3. Петрифікація тканини IPHT. Забарвлення гематоксиліном та еозином (А) та алізариновим червоним S (Б). Збільшення $\times 100$

Посилення інтенсивності імунної відповіді, а також тенденції до петрифікації спостерігається при прогресуванні неопластичного процесу та зростанні злоякісності пухлин. Більш яскраво це відбувається за умови набуття раковими клітинами вираженого поліморфізму. Відмічається поєднання патологічної мінералізації в тканині молочної залози та запальною інфільтрацією.

Ступінь ангіогенезу неопластичної тканини також залежить від ступеню диференціювання пухлин. Для більш злоякісних карцином притаманне переважання капілярного типу васкуляризації зі значно меншою кількістю більш товстостінних судин (венул та артеріол).

\section{2. Імуногістохімічні особливості IPHT}

Під час проведення імуногістохімічного дослідження встановлено, що тканина IPHT у 78\% випадків має ядерну експресію ЕР (клон SP1). Керуючись рекомендаціями D.C.Allred, виявлено, що серед них слабопозитивна реакція спостерігається у $31 \%$ випадків, помірнопозитивна - у 23\% та сильно-позитивна - у 46\% випадків (рис. 4-A). Щодо ПР (клон YR85), то встановлено, що ракова тканина експресує ці рецептори у $62 \%$ випадків. Серед них слабо-позитивна реакція виявлена у $43 \%$ випадків, помірнопозитивна реакція у $31 \%$ та сильнопозитивна реакція - у 26\% випадків. Більшість випадків РМЗ характеризується гетерогенною експресію рецепторів, коли у пухлинній тканині присутні як рецептор-негативні, так рецепторпозитивні неопластичні клітини з різною інтенсивністю експресії ЕР та ПР (рис. 4-Б). 
Спостерігається сильний позитивний кореляційний зв'язок між експресією ЕР та ПР. Дедиференціювання IPHТ та наявність запальної інфільтрації в пухлинному мікрооточені супроводжуються зниженням чутливості ракових клітин до статевих гормонів.

Експресію HER2/neu (клон SP3) у неопластичній тканині виявлено у $20 \%$ випадків, яка проявлялася інтенсивним суцільним забарвленням мембрани пухлинних клітин (рис. 4-B). Наявність HER2/neu спостерігалась значно частіше y high-grade пухлинах із стероїднегативним імуногістохімічним профілем. Подібно експресії ЕР та ПР, під час дослідження HER2/neu виявляються випадки з гетерогенною реакцією, що $\epsilon$ індикатором мінливості рецепторного фенотипу неопластичних клітин при прогресуванні злоякісного процесу.

Імуногістохімічні особливості метастатичної тканини у лімфатичних вузлах у більшості випадків співпадають із рецепторним профілем пухлинних клітин у первинному вогнищі - лише іноді спостерігається пригнічення сигналу ER та PR у метастазах.

Індекс проліферації, оцінений за допомогою дослідження ядерної експресії Кі-67 (клон SP6), у тканині IPHT характеризується вираженою гетерогенністю. Проліферативний потенціал неопластичної тканини у переважній більшості випадків перевищував інтенсивність поділу клітин у відносно-нормальній навколишній тканині молочної залози. Натомість кількість Кі-67-позитивних клітин була більшою в метастатичних вогнищах по відношенню до першоджерела. Так, слабопозитивна реакція $(1 \%<\mathrm{n}<14 \%)$ виявлена у $40 \%$ випадків, помірнопозитивна $(14 \%<\mathrm{n}<30 \%)-$ у $37 \%$ та сильнопозитивна $(30 \%<\mathrm{n}<100 \%)-$ у $23 \%$ випадків (рис. $4-\Gamma)$. Серед неопластичної тканини зустрічалися як «гарячі» імуногістохімічні ділянки 3 вираженою експресією Кі-67 у переважній більшості клітин, так і «холодні» вогнища при майже повній відсутності поділу в ракових клітинах. Більш високі показники індексу проліферації виявляються у тканині IPHТ з відсутньою та слабкою експресією ЕР та ПР.

Дослідження експресії білків p53 (SP5) та bcl-2 (100/D5) дозволяє визначити проапоптичний та антиапоптичний потенціал пухлинних клітин IPHТ молочної залози. Серед усіх випадків позитивна експресія (інтенсивне забарвлення ядер більше 5\% клітин) р53 виявлена у 40\% випадків. Серед них слабопозитивна реакція $(5 \%<\mathrm{n}<20 \%)$ визначається $32 \%$ випадків, помірнопозитивна - $(20 \%<\mathrm{n}<50 \%)-$ у $47 \%$ та сильнопозитивна $(50 \%<\mathrm{n}<100 \%)-$ у $21 \%$ випадків (рис. 5). Метастатична тканина характеризується значно вищими показниками експресії p53. Зростання експресії p53 спостерігається при дедиференціюванні новоутворень та набутті раковими клітинами 
вираженого поліморфізму, а також при зростанні проліферативної активності ракових клітин.

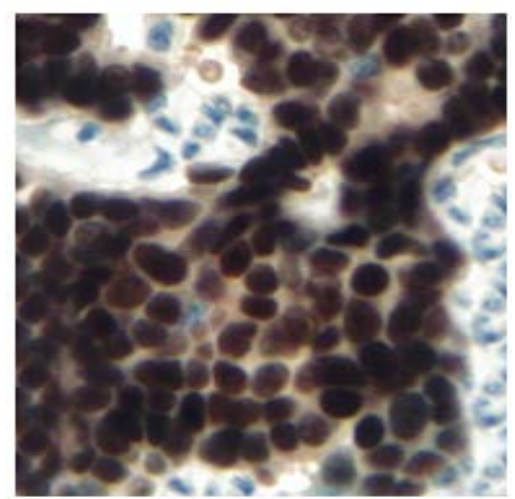

A

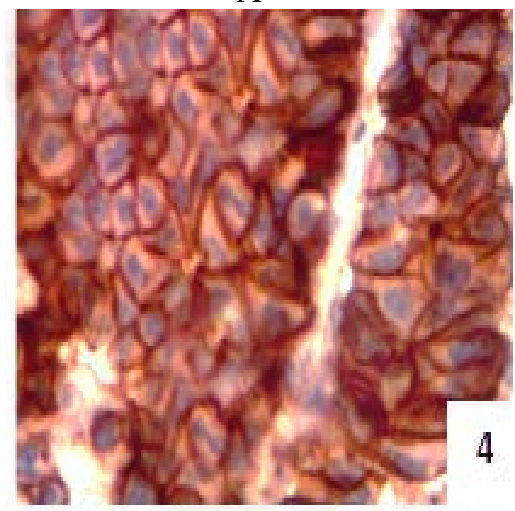

B

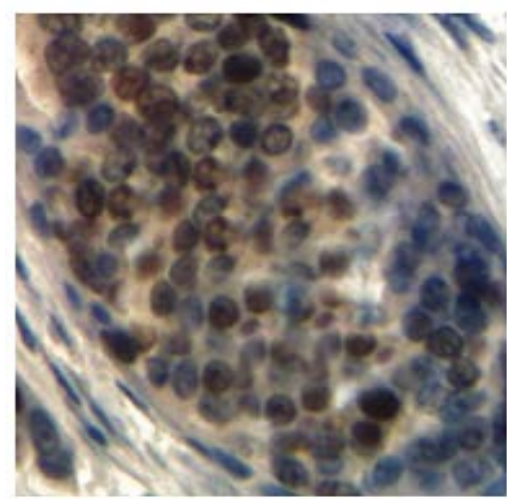

Б

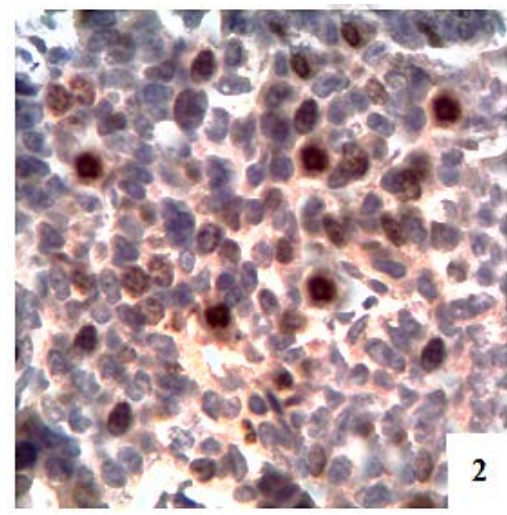

$\Gamma$

Рис. 4. ІРНТ. ІГХ дослідження експресії ЕР (А), ПР (Б), HER2/neu (B) та Кi-67 (Г). Збільшення $\times 400$

Експресія раковими клітинами bcl-2 у цитоплазмі $\epsilon$ індикатором антиапоптозного їхнього потенціалу. Позитивну реакцію виявлено у 56\% випадків (рис. 5). Наявність цих білків супроводжується рецепторпозитивним профілем клітин до ЕР, оскільки ген Bcl-2 є естроген залежним, транскрипція якого відбувається при надходженні сигналів від ЕР. Спостерігається позитивний кореляційний зв'язок між експресіями bcl-2 та p53, що вказує на взаємозв'язок між цими двома регуляторами апоптозу. 


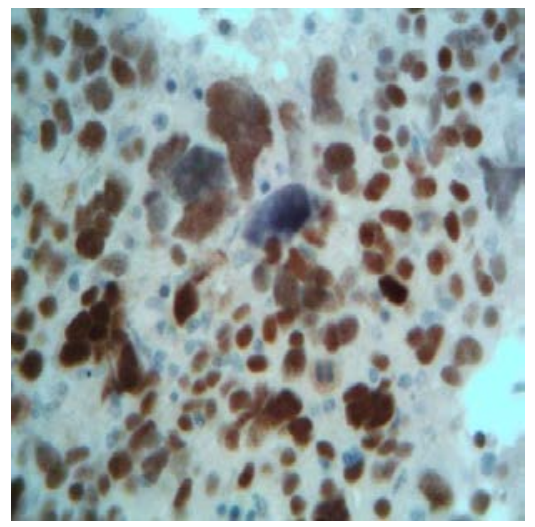

p53

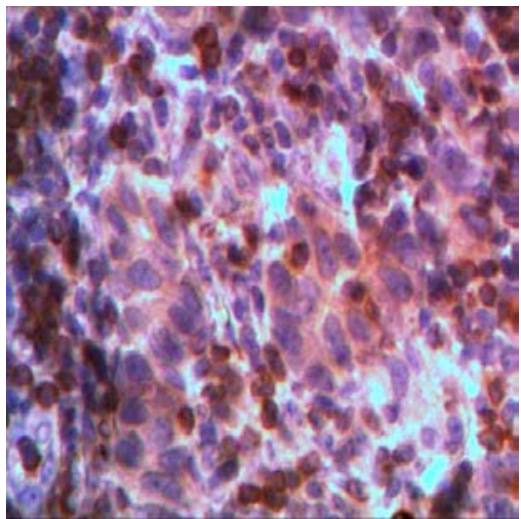

bcl-2

Рис. 5. ІРНТ. ІГХ дослідження експресії p53 та bcl-2. Збільшення ×400

Експресія ММП1 (поліклон) є індикатором інвазивного потенціалу пухлин. Ці білки, проявляючи колагеназну активність, беруть учать у розрідженні строми та поширенні неопластичних клітин в оточуючі ділянки та судини. Тканина IPHT характеризується позитивною цитоплазматичною експресією ММП1 у ракових клітинах у 57,5\% (рис 6). Слід зазначити, що деякі клітини строми також мають позитивну експресію цих білків. Більш виражене накопичення ММП1 спостерігається в периферичних ділянках неопластичної тканини, що вказує на безпосередню їхню участь у розповсюдженні пухлин. Під час контакту ракових клітин зі стромою за рахунок розчинення останньої виникають лакуни, в які і проникають неопластичні клітини.

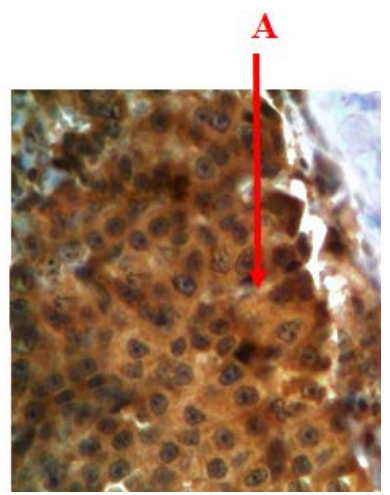

A

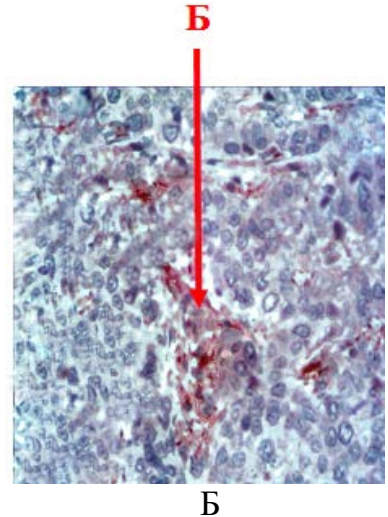

Б

Рис. 6. ІРНТ. ІГХ дослідження експресії ММР1.

А - клітини пухлини, Б - клітини строми. Збільшення $\times 400$ 
Усі 100\% пухлин є Е-кадгерин-позитивними (клон 67А4). Більш того, цей маркер є індикатором IPHТ молочної залози, який дозволяє віддиференціювати цей тип карциноми від інших злоякісних епітеліальних пухлин у молочній залозі. Щодо ступеню експресії, то слабопозитивна реакція спостерігається 37,5\% випадків, помірнопозитивна - у 37,5\% та сильнопозитивна - у 25\% випадків (рис. 7). Установлена протилежно спрямована залежність між експресіями ММП1 та Е-кадгерину, а також зростання метастатичного потенціалу клітин при пригніченні ексгібіції адгезивних білків.

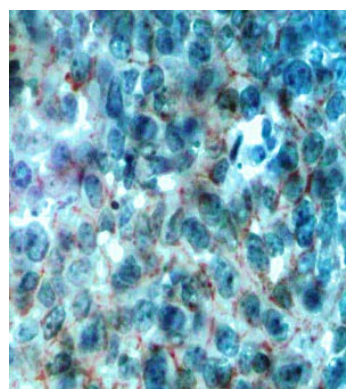

1

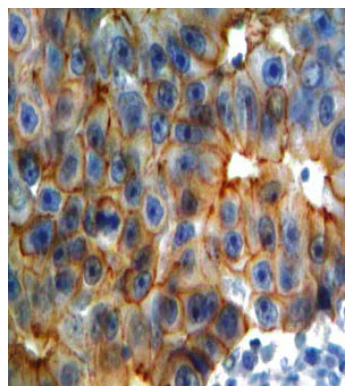

2

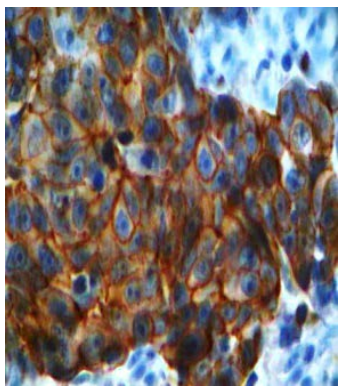

3

Рис. 7. IPHT. IГX дослідження експресії Е-кадгерину.

1 - слабопозитивна, 2 - помірнопозитивна

та 3 - сильнопозитивна мембранна реакція. Збільшення $\times 400$

При імуногістохімічному дослідженні встановлено, що експресія ЕСФР (поліклон) у цитоплазмі неопластичних клітин наявна у 70\%, серед яких слабопозитивна реакція спостерігається у 43\%, помірнопозитивна - у 47\% та сильно-позитивна - у $10 \%$ випадків (рис. 8).

Позитивна реакція спостерігається також у клітинах строми пухлини та ендотелії судин, підкреслюючи їхню участь у ангіогенезі пухлин.
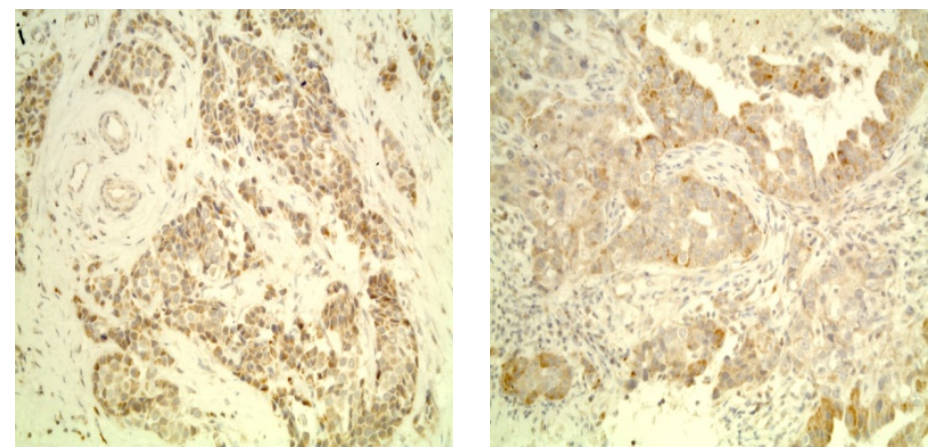

Рис. 8. ІРНТ. ІГХ дослідження рецепторів ЕСФР. Збільшення ×400 
Посилення рівня експресії ЕСФР під час дедиференціювання новоутворень МЗ супроводжується зростанням васкуляризації пухлини та віддаленим метастазуванням карцином.

Експресія остеопонтину (поліклон) спостерігається лише у тканині IPHT із петрифікацією. Серед усіх випадків пухлинної тканини 3 біомінералізацією наявність остеопонтину в неопластичних клітинах виявляється у 55\% випадків. У переважній більшості наявна слабо- та помірнопозитивна реакція, i лише іноді (близько 10\%) сильнопозитивна реакція (рис. 9-А). Зростання рівня злоякісності пухлин супроводжується посиленням експресії остеопонтину.

Експресія шаперону $90 \alpha$ (поліклон) у пухлинних клітинах виявлено у цитоплазмі та ядрі в різних співвідношеннях. Позитивну реакцію різної інтенсивності виявлено у майже $80 \%$ випадків ІРНТ (рис. 9-Б). Рівень експресії цього білка посилюється при зростанні інфільтрації пухлин імуноцитами. Усі HER2/neu-позитивні новоутворення супроводжуються наявністю шаперону $90 \alpha$. Установлено негативний кореляційний зв'язок між експресією рецепторів ЕР та ПР i шаперонами, що вказує на участь цих білків у блокуванні гормональнозалежного фенотипу ракових клітин.

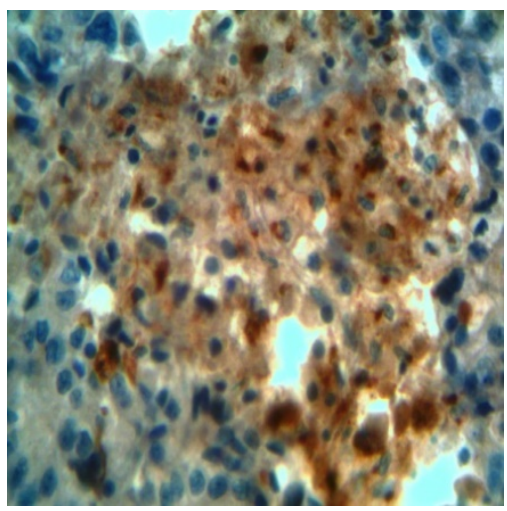

A

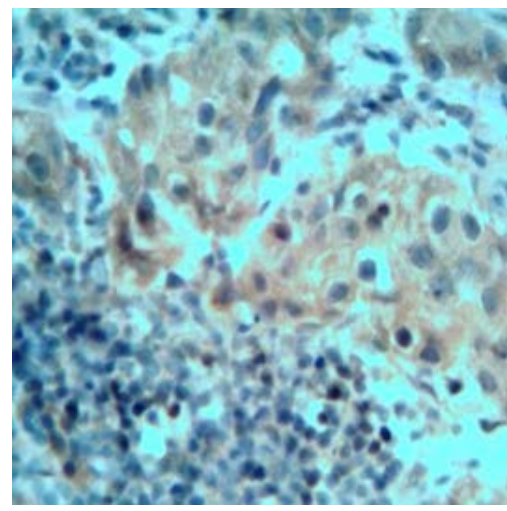

Б

Рис. 9. ІРНТ. ІГХ дослідження рецепторів остеопонтину (А) та шаперону 90 (Б). Збільшення $\times 400$

Дослідження якісного складу пухлинного імунного мікрооточення показало, що В-лімфоцити у ньому (експресія CD79 $\alpha$, клон SP18) складають від 20\% до 60\% (рис. 10-А), а Т-лімфоцити (експресія CD3, клон SP7) - від 25\% до 70\% (рис. 10-Б). Взагалі на частку лімфоцитів припадає $85-90 \%$ серед усіх форм лейкоцитів мікрооточення. Гранулоцити (експресія мієлопероксидази, поліклон) у 
навколопухлинному просторі займають лише від 1\% до 7\% (рис. 10-В), тоді як на долю макрофагів (експресія S100, клон 4C4.9) припадає не більше як $15 \%$ від всіх форм лейкоцитів (рис. 10-Г). S100-позитивні клітини мають відростки, якими огортають пухлинні клітини. Вони розташовувались розрізнено як серед імуноцитів, так i серед неопластичних клітин. При накопиченні В-лімфоцитів відбувається зменшення рівня експресії ЕР та ПР. Отже, якісні характеристики ракової тканини залежать не тільки від самого факту наявності запалення навколо пухлинних клітин, а більшою мірою від якісного складу імунного інфільтрату.

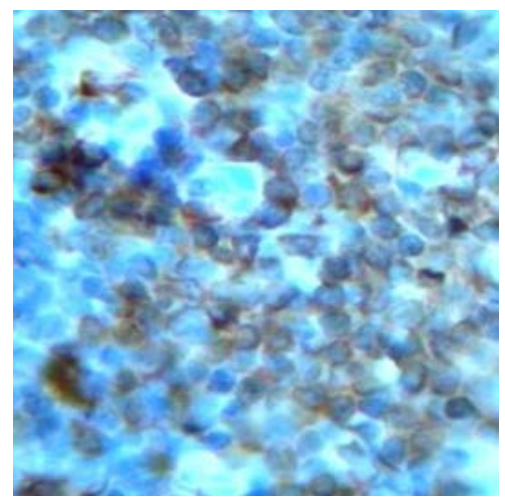

A

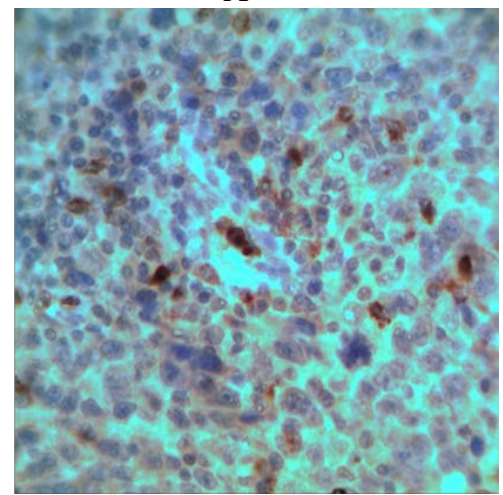

B

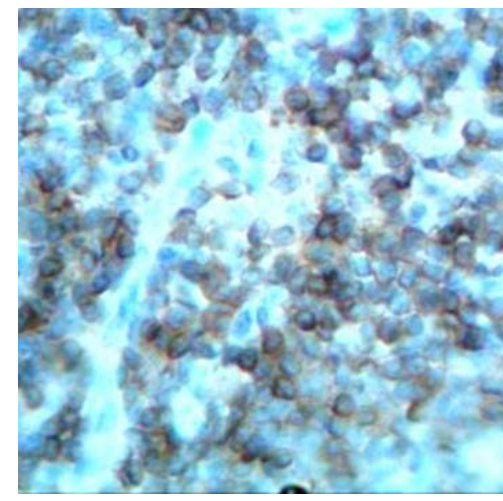

Б

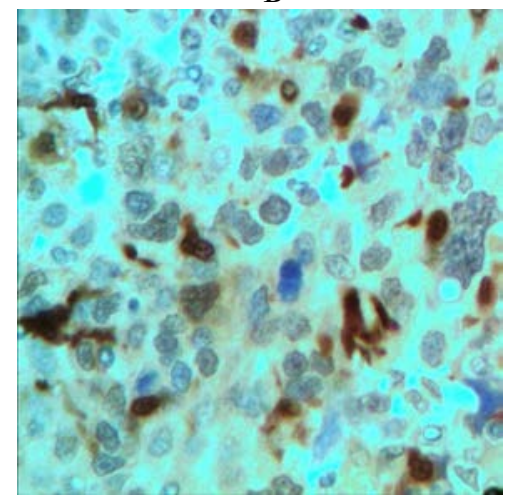

$\Gamma$

Рис. 10. IPHT. Імунний інфільтрат у стромі IPHT. ІГХ дослідження рецепторів CD79a (A), CD3 (Б), мілопероксидази (В) та S100 (Г). Збільшення ×400 
Тканина IPHТ характеризується варіабельною васкуляризацією, яку встановлено за допомогою імуногістохімічного дослідження рецепторів CD31 (клон 1A10). Для low-grade пухлин притаманна наявність різнокаліберних судин із невисокою мікросудинною щільністю непластичної тканин. Низькодиференційовані пухлини мають значно менший відсоток «зрілих» судин та більшу мікросудинну щільність (рис. 11). Спостерігається зростання щільності капілярів при надекспресії VEGF. Слід зазначити, що всі CD31-позитивні структури, виявлені в карциномах, розцінюються або як повноцінні судини (капіляри), або їх попередники (навіть при відсутності в них просвітів). У пухлинній тканині виявлені як ділянки із вираженою мікросудинною щільністю, так і гіповаскуляризовані вогнища.

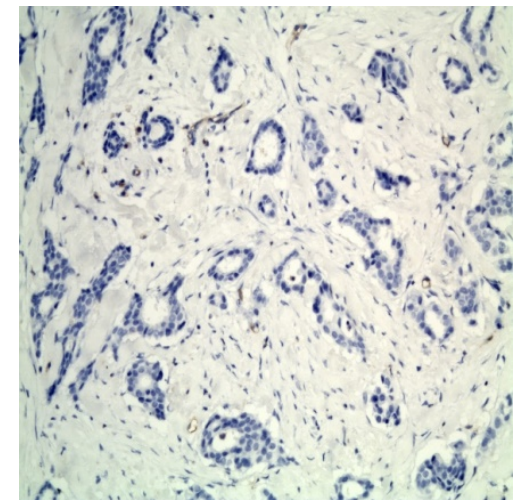

A

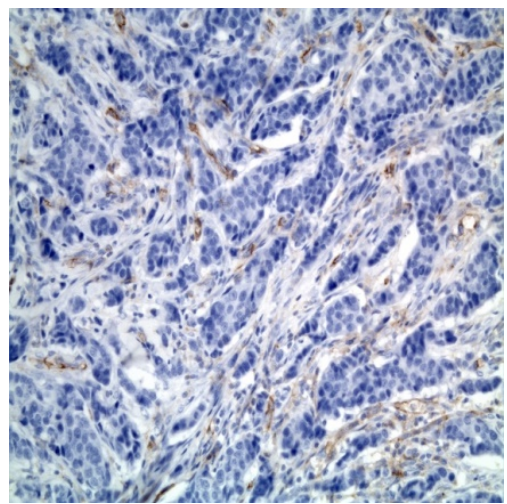

Б

Рис. 11. IPHT. IГХ дослідження рецепторів CD31. Збільшення $\times 400$

\section{ВИСНОВКИ}

Рак молочної залози займає одну з лідируючих позицій у структурі онкологічної захворюваності в Україні. Серед усіх гістологічних форм найбільш розповсюдженим варіантом ураження $\epsilon$ інвазивний рак неспецифічного типу. Цей вид карцином характеризується дуже варіабельними особливостями як паренхіматозного компоненту, так і їх строми. Ступінь диференціювання пухлин, наявність патологічної біомінералізації та інтенсивність вираженості імунної реакції в пухлинному мікрооточенні впливають на перебіг злоякісного процесу та його розповсюдження.

При імуногістохімічному дослідженні виявлено, що тканина інвазивного раку неспецифічного типу у $78 \%$ випадків має експресію ЕР, у $62 \%$ - ПР, у $20 \%$ - HER $2 /$ neu, y $40 \%$ - p53, y $56 \%$ - bcl-2, 57,5\% -

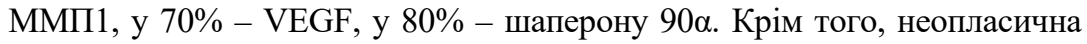


тканина проявляе різний ступінь проліферативної активності та неоваскуляризації, а також варіабельний склад імунного мікрооточення. Імунопрофіль пухлини залежить як від експресії окремих білків у пухлинній тканині, так і від ступеню диференціювання пухлин та якісних характеристик імунного мікрооточення.

Гістологічні та імуногістохімічні особливості раку молочної залози відображаються на місцевому та віддаленому розповсюдженні пухлин, що, без сумніву, впливає на перебіг захворювання та виживаність пацієнтів.

\section{АНОТАЦІЯ}

Рак молочної залози займає одну з головних позицій у структурі онкологічної патології - за останні 10 років цей показник у середньому складає 64,51 $\pm 2,85$ на 100 тис. населення. Більшість випадків (99,2\%) виявлено в пацієнтів жіночої статі, і лише $0,8 \%$ випадків спостерігалося в чоловіків. Перебіг захворювання залежить не тільки від особливостей паренхіматозного компоненту пухлин, але i також від якісних характеристик строми. Рецепторний профіль неопластичних клітин при цьому має один із найпотужніших прогностичних i терапевтичних впливів. Серед усіх гістологічних форм раку молочної залози більша половина випадків має гістологічний діагноз «Інвазивний рак неспецифічного типу» різного ступеню диференціювання. При імуногістохімічному дослідженні виявлено, що тканина інвазивного раку неспецифічного типу у 78\% випадків має експресію ЕР, у $62 \%$ - ПР, у $20 \%$ - HER2/neu, y $40 \%$ - p53, y 56\% - bcl-2, 57,5\% - MMП1, у 70\% VEGF, у $80 \%$ - шаперону $90 \alpha$. Крім того, неопласична тканина проявляє різний ступінь проліферативної активності та неоваскуляризації, а також варіабельний склад пухлинного мікрооточення. Усі якісні та кількісні параметри пухлинної тканини впливають на перебіг захворювання та виживаність пацієнтів

\section{ЛITЕРАТУРА}

1. Wu Y., Zhang D., Kang S. Physical activity and risk of breast cancer: a meta-analysis of prospective studies. Breast Cancer Res Treat. 2013. Vol. 137, № 3. P. 869-882. doi:10.1007/s10549-012-2396-7.

2. Suba Z. Triple-negative breast cancer risk in women is defined by the defect of estrogen signaling: preventive and therapeutic implications. Onco Targets Ther. 2014. Vol. 7. P. 147-164. doi:10.2147/OTT.S52600.

3. Apostolou P., Fostira F. Hereditary breast cancer: the era of new susceptibility genes. Biomed Res Int. 2013. 2013:747318. doi:10.1155/2013/747318. 
4. Tavassoli F.A., Devilee P. Tumor of the Breast and female genital organs. World Health Organization Classification of Tumours : Lyon : IARC Press, 2003. 432 p.

5. Lakhani S.R., Ellis I.O., Schnitt S.J., Tan P.H. Invasive carcinoma of no special type. WHO Classification of Tumours of the Breast : Lyon, 2012. P. 34-38.

6. Sørlie T., Perou C.M., Tibshirani R., et al. Gene expression patterns of breast carcinomas distinguish tumor subclasses with clinical implications. Proc Natl Acad Sci U S A. 2001. Vol. 98, № 19. P. 10869-10874. doi:10.1073/pnas.191367098.

7. Cox R.F., Hernandez-Santana A., Ramdass S., McMahon G., Harmey J.H., Morgan M.P. Microcalcifications in breast cancer: novel insights into the molecular mechanism and functional consequence of mammary mineralisation. Br J Cancer. 2012. Vol. 106, № 3. P. 525-537. doi:10.1038/bjc.2011.583.

8. Keibel A., Singh V., Sharma M.C. Inflammation, microenvironment, and the immune system in cancer progression. Curr Pharm Des. 2009. Vol. 15, № 17. P. 1949-1955. doi:10.2174/138161209788453167.

9. Ruffell B., Au A., Rugo H.S., Esserman L.J., Hwang E.S., Coussens L.M. Leukocyte composition of human breast cancer. Proc Natl Acad Sci U S A. 2012. Vol. 109, № 8. P. 2796-2801. doi:10.1073/pnas.1104303108.

10. Lindström L.S., Karlsson E., Wilking U.M., et al. Clinically used breast cancer markers such as estrogen receptor, progesterone receptor, and human epidermal growth factor receptor 2 are unstable throughout tumor progression. J Clin Oncol. 2012. Vol. 30, № 21. P. 2601-2608. doi:10.1200/JCO.2011.37.2482.

11. Esslimani-Sahla M., Kramar A., Simony-Lafontaine J., Warner M., Gustafsson J.A., Rochefort H. Increased estrogen receptor betacx expression during mammary carcinogenesis. Clin Cancer Res. 2005. Vol. 11, № 9. P. 3170-3174. doi:10.1158/1078-0432.CCR-04-2298.

12. Glück S., Arteaga C.L., Osborne C.K. Optimizing chemotherapy-free survival for the ER/HER2-positive metastatic breast cancer patient. Clin Cancer Res. 2011. Vol. 17, № 17. P. 5559-5561. doi:10.1158/10780432.CCR-10-2051.

13. Weigel M.T., Dowsett M. Current and emerging biomarkers in breast cancer: prognosis and prediction. Endocr Relat Cancer. 2010. Vol. 17, № 4. P. R245-R262. doi:10.1677/ERC-10-0136.

14. Al-azawi D., Leong S., Wong L., Kay E., Hill A.D., Young L. HER-2 positive and p53 negative breast cancers are associated with poor prognosis. Cancer Invest. 2011. Vol. 29, № 5. P. 365-369. doi:10.3109/ 07357907.2011.584586. 
15. Martin L.A., Dowsett M. BCL-2: a new therapeutic target in estrogen receptor-positive breast cancer?. Cancer Cell. 2013. Vol. 24, № 1. P. 7-9. doi:10.1016/j.ccr.2013.06.006.

16. Wang X., Chao L., Ma G., et al. Primary breast carcinoma: association of mammographic calcifications with osteopontin expression. Radiology. 2010. Vol. 254, № 1. P. 69-78. doi:10.1148/radiol.2541090675.

17. Grbovic O.M., Basso A.D., Sawai A., et al. V600E B-Raf requires the Hsp90 chaperone for stability and is degraded in response to Hsp90 inhibitors. Proc Natl Acad Sci U S A. 2006. Vol. 103, № 1. P. 57-62. doi:10.1073/pnas.0609973103.

18. Kaimal R., Aljumaily R., Tressel S.L., et al. Selective blockade of matrix metalloprotease-14 with a monoclonal antibody abrogates invasion, angiogenesis, and tumor growth in ovarian cancer. Cancer Res. 2013. Vol. 73, № 8. P. 2457-2467. doi:10.1158/0008-5472.CAN-12-1426.

19. Brzozowska A., Sodolski T., Duma D., Mazurkiewicz T., Mazurkiewicz M. Evaluation of prognostic parameters of E-cadherin status in breast cancer treatment. Ann Agric Environ Med. 2012. Vol. 19, № 3. P. 541-546.

20. Li X., Lee C., Tang Z., et al. VEGF-B: a survival, or an angiogenic factor? Cell Adh Migr. 2009. Vol. 3, № 4. P. 322-327. doi: 10.4161/cam.3.4.9459.

\section{Information about authors:}

Lyndin M. S., $\mathrm{MD}, \mathrm{PhD}$,

Associate Professor of Pathology Department Sumy State University

31 Pryvokzalna Str., Sumy, 40022, Ukraine

Romaniuk A. M., MD, DM, Professor, Head of Pathology Department Sumy State University 31, Sumy, Pryvokzalna Str., 40022, Ukraine 